Supporting Information for

\title{
Synergistic Effects of Inexpensive Mixed Metal Oxides for Catalytic Hydrothermal Liquefaction of Food Wastes
}

Feng Cheng ${ }^{1}$, Geoffrey A. Tompsett ${ }^{1}$, Caroline M. Murphy ${ }^{l}$, Alex R. Maag ${ }^{1}$, Nicholas Carabillo $^{1}$, Marianna Bailey ${ }^{1}$, Jeremy J. Hemingway ${ }^{1}$, Carla I. Romo ${ }^{1}$, Alex D. Paulsen ${ }^{2}$, Paul E. Yelvington ${ }^{2}$, and Michael T. Timko ${ }^{1}$,

${ }^{1}$ Department of Chemical Engineering, Worcester Polytechnic Institute, 100 Institute Rd., Worcester, MA 01609, USA.

${ }^{2}$ Mainstream Engineering Inc, 200 Yellow Place, Rockledge, FL 32955, USA.

Department of Chemical Engineering, Worcester Polytechnic Institute, 100 Institute Rd., Worcester, MA 01609, USA. Tel. +1-508-831-4101

*Corresponding Author E-mail: mttimko@wpi.edu

Number of pages: 21

Number of figures: 11

Number of tables: 6

Section 1 Characterization procedure of inexpensive oxides, component oxides, and bio-crude oils

Section 2 Preparation of food waste, characterization and leaching test of inexpensive oxides and component oxides, and characterization of bio-crude oils

Section 3 Hydrothermal stability of inexpensive oxides and component oxides

Section 4 Characterization of inexpensive oxides, component oxides, and bio-crude oils 


\section{Section 1 Characterization procedure of inexpensive oxides, component oxides, and bio-crude oils}

Acid and base site densities of the oxide catalysts were determined using $\mathrm{NH}_{3}-$ and $\mathrm{CO}_{2}$ temperature programmed desorption (TPD) analysis, respectively. A Quantachrome Autosorb iQ adsorption/chemisorption system equipped with a thermal conductivity detector (TCD), was used for the TPD analysis. The TPD methods used were similar to those reported by Rodrigues et al., ${ }^{1}$ and Käßner et al. ${ }^{2}$ Only calcium oxide was calcined in air (at $550{ }^{\circ} \mathrm{C}$ for 3 hours) prior to TPD analysis. Samples were degassed under continuous flow of helium $\left(20 \mathrm{~cm}^{3} \mathrm{~min}^{-1}\right)$ at different temperatures (as seen in Table S6), followed by cooling to $30^{\circ} \mathrm{C}$. After degassing, samples were then saturated under $\mathrm{CO}_{2}$ gas flow for 10 minutes at $30{ }^{\circ} \mathrm{C}$, after which the sample cell was purged with helium for 30 minutes at $30{ }^{\circ} \mathrm{C}$ to remove excess $\mathrm{CO}_{2}$. The $\mathrm{CO}_{2}$-adsorbed sample was then heated from 30 to $800{ }^{\circ} \mathrm{C}$ at a heating rate of $10{ }^{\circ} \mathrm{C} \mathrm{min}^{-1}$ under helium, and the $\mathrm{CO}_{2}$ off-gas was quantified using a TCD detector.

A similar method was used for $\mathrm{NH}_{3}$-TPD analysis to quantify acid sites. ${ }^{3}$ Samples were degassed under continuous helium flow for 120 minutes, cooled to $100^{\circ} \mathrm{C}$, and the sample saturated under continuous $\mathrm{NH}_{3}$ flow for 10 min. Degassing temperatures were set based on the thermal stability of the material, with details provided in Table $\mathrm{S} 6$. After $\mathrm{NH}_{3}$ saturation, the sample cell was purged under continuous helium flow for $30 \mathrm{~min}$, heated to $800{ }^{\circ} \mathrm{C}$ at a rate of $2{ }^{\circ} \mathrm{C} \mathrm{min}-1$, and finally flushed with helium for 30 minutes. The off-gas was continuously monitored by a TCD detector.

TPD calibration curves were generated using a range of measured volumes of $\mathrm{NH}_{3}$ and $\mathrm{CO}_{2}$. The areas under the standard TPD curves were calculated using Magicplot software. The base and acid site densities were calculated as $\mu \mathrm{mol} \mathrm{g}{ }^{-1}$ using TCD response factors.

The mass percentage of metal oxide components in red mud, red art clay and fly ash was quantitatively measured by Total Reflection X-ray Fluorescence (S2 Picofox, Bruker Co., 
Billerica, MA, USA). ${ }^{4}$ All three materials are predominantly composed of silica, alumina, and iron oxide differing mainly in the relative abundance of these three oxides and the presence or absence of other oxides (e.g. calcium, potassium, and sodium oxide). Table S3 provides compositional details for red mud, red art clay, and fly ash. Red clay contained primarily silica, with lesser quantities of alumina and iron oxide. Red mud contained roughly equal amounts of silica, alumina, and iron oxide, as well as substantial amounts of calcium and sodium oxide. The fly ash used here consists primarily of silica with substantial alumina content.

The crystallinity of catalyst materials was characterized by X-ray diffraction (XRD) before and after use. An X-ray Powder Diffractometer (Geigerflex, Rigaku Co., Tokyo, Japan) with the Bragg-Bretano theta-theta configuration, using a $\mathrm{CuK} \alpha$ radiation at $27.5 \mathrm{kV}$ and $25 \mathrm{~mA}$ was used for all characterization. Spectra were obtained in the $2 \theta$ range from 6 to $80^{\circ}$ with a step of $0.02^{\circ}$.

The oxide phases present in the catalyst materials were further analyzed using Raman spectroscopy (Xplora, Horiba Scientific, Piscataway, NJ, USA). An excitation laser operating at $532 \mathrm{~nm}$ and an Olympus $100 \times$ magnification lens were used for all tests. The laser power was maintained at $1-5 \mathrm{~mW}$ and the spot size was estimated as approximately $2 \mu \mathrm{m}$. The spectra presented here was obtained by averaging $2 \mathrm{~s}$ and $10 \mathrm{~s}$ scans. Spectra from multiple particles were obtained to ensure that representative spectra had been obtained.

The morphology of fresh and used catalysts were characterized using scanning electron microscope (SEM) (JSM 7000F SEM, JEOL Ltd., Tokyo, Japan). The particle size of catalysts was determined directly from SEM images.

Gas chromatography was performed on a SHRXI-5MS $(30 \mathrm{~m} \times 0.25 \mathrm{~mm}$ ID $\times 0.5 \mu \mathrm{m}$ film thickness) (Restek Co., Bellefonte, PA), with an injection temperature of $290^{\circ} \mathrm{C}$ and the ion source at $260{ }^{\circ} \mathrm{C}$. A $4 \mu \mathrm{L}$ sample was injected into the GC-MS system in a split mode (25:1). The helium 
carrier gas was set at a constant flow rate of $3.0 \mathrm{~mL} / \mathrm{min}$. The temperature program started at $30^{\circ} \mathrm{C}$ holding for $4 \mathrm{~min}$, followed by heating up to $290{ }^{\circ} \mathrm{C}$ with a heating rate of $3{ }^{\circ} \mathrm{C} / \mathrm{min}$, and held at $290{ }^{\circ} \mathrm{C}$ for $5 \mathrm{~min}$. The mass spectrometer was operated in ionization energy in $\mathrm{m} / \mathrm{z} 35-500 \mathrm{scan}$ range. All chromatogram peaks were evaluated using the GCsolution Station (Shimadzu Co., Kyoto, Japan). Chromatogram peaks were compared with NIST Mass Spectral Database (NIST11). The comparison between samples were completed as all data were normalized to the highest peak: 9-Octadecenamide.

Proton nuclear magnetic resonance spectroscopy was conducted based on the following procedure: bio-crude oil $(\sim 10 \mathrm{mg})$ was dissolved in $560 \mu \mathrm{l}$ of deuterated chloroform $\left(\mathrm{CDCl}_{3}\right)$ (Cambridge Isotope Laboratories, D 99.8\%) containing $0.03 \%(\mathrm{v} / \mathrm{v})$ tetramethylsilane (TMS). The ${ }^{1} \mathrm{H}$ NMR spectra were acquired using a $5 \mathrm{~mm}$ Prodigy $\mathrm{BBO}$ cryoprobe, $30^{\circ}$ pulse, $1 \mathrm{sec}$ relaxation delay, $8013 \mathrm{~Hz}$ sweep width, $2.2 \mathrm{sec}$ acquisition time, 64 scans, and 8 dummy scans, with $20 \mathrm{~Hz}$ rotation at $300 \mathrm{~K}$. 
Section 2 Preparation of food waste, characterization and leaching test of inexpensive oxides and component oxides, and characterization of bio-crude oils

Table S1. List of solid ingredients in the food waste feedstock and a list of feedstock properties.

\begin{tabular}{lc|lc}
\hline Food Item & $\begin{array}{c}\text { Feedstock } \\
\text { Percent } \\
\text { (Dry Basis) }\end{array}$ & $\begin{array}{l}\text { Feedstock Composition and } \\
\text { HHV }\end{array}$ & $\begin{array}{c}\text { Value } \\
(w t \% \text { or } \\
\text { MJ/kg) }\end{array}$ \\
\hline American & 12.8 & Moisture (wt\%) & 73.0 \\
Cheese & 14.9 & Proteins, bone dry (wt\%) & 17.8 \\
Canned Chicken & 10.6 & Lipids, bone dry (wt\%) & 21.9 \\
Instant Potatoes & 14.9 & Carbohydrates, bone dry (wt\%) & 58.9 \\
Green Beans & 19.1 & Ash, bone dry (wt\%) & 1.1 \\
White Rice & 22.3 & HHV, bone dry (MJ/kg) & 24.6 \\
Apple Sauce & 5.4 & HHV, wet (MJ/kg) & 6.5 \\
Butter & &
\end{tabular}

Table S2. Catalyst stability - remaining metal contents in catalysts and concentration of leached metal components in the aqueous phase obtained after 1-hour catalytic hydrothermal liquefaction of $15 \mathrm{wt} \%$ food waste at $300^{\circ} \mathrm{C}$ and $20.7 \mathrm{MPa}$.

\begin{tabular}{lllllll}
\hline Catalyst & $\begin{array}{l}\text { Iron (III) } \\
\text { Oxide }\end{array}$ & $\begin{array}{l}\text { Calcium } \\
\text { Oxide }\end{array}$ & Alumina & $\begin{array}{l}\text { Red } \\
\text { Clay }\end{array}$ & $\begin{array}{l}\text { Red } \\
\text { Mud }\end{array}$ & $\begin{array}{l}\text { Fly } \\
\text { Ash }\end{array}$ \\
\hline $\begin{array}{l}\text { Remaining aluminum } \\
\text { content (wt\%) }\end{array}$ & N.A. & N.A. & 99.93 & 99.92 & 99.93 & $>99.99$ \\
$\begin{array}{l}\text { Remaining calcium } \\
\text { content (wt\%) }\end{array}$ & N.A. & 95.81 & N.A. & 92.49 & 99.96 & 98.85 \\
$\begin{array}{l}\text { Remaining iron } \\
\text { content (wt\%) }\end{array}$ & 99.67 & N.A. & N.A. & 98.96 & $>99.99$ & $>99.99$ \\
$\begin{array}{l}\text { Leached aluminum } \\
\text { concentration in } \\
\text { aqueous (ppm) }\end{array}$ & N.A. & N.A. & 21.96 & 4.08 & 3.94 & 0.31 \\
$\begin{array}{l}\text { Leached calcium } \\
\text { concentration in } \\
\text { aqueous phase (ppm) }\end{array}$ & N.A. & 1756.90 & N.A. & 16.15 & 2.47 & 6.69 \\
$\begin{array}{l}\text { Leached iron } \\
\text { concentration in } \\
\text { aqueous phase (ppm) }\end{array}$ & 136.23 & N.A. & N.A. & & & \\
\hline
\end{tabular}


Table S3. Composition ( $\mathrm{wt} \%$ ) of the component oxide materials.

\begin{tabular}{llllllllllll}
\hline Catalyst & $\mathbf{S i O}_{\mathbf{2}}$ & $\mathbf{A l}_{\mathbf{2}} \mathbf{O}_{\mathbf{3}}$ & $\mathbf{F e}_{\mathbf{2}} \mathbf{O}_{\mathbf{3}}$ & $\mathbf{C a O}$ & $\mathbf{M g O}$ & $\mathbf{N a}_{\mathbf{2}} \mathbf{O}$ & $\mathbf{K}_{\mathbf{2}} \mathbf{O}$ & $\mathbf{S O}_{\mathbf{3}}$ & $\mathbf{M n O}$ & $\mathbf{P}_{\mathbf{2}} \mathbf{O}_{\mathbf{5}}$ & $\mathbf{T i O}_{\mathbf{2}}$ \\
\hline Red clay & 63.7 & 15.2 & 7.9 & 0.5 & & & 4.1 & & & 0.3 & \\
& & & & & & & & & & & \\
Red mud $^{4}$ & 28.7 & 18.9 & 21.8 & 15.4 & 0.34 & 5.5 & 1.5 & & 0.5 & 3.1 & 4.3 \\
Fly ash $^{4}$ & 62.1 & 29.4 & 6.8 & 1.4 & & & & 0.23 & & & \\
\hline
\end{tabular}


Table S4. Proton type distribution in bio-crude oils obtained from HTL and CHTL of $15 \mathrm{wt} \%$ food waste using different catalysts under $300{ }^{\circ} \mathrm{C}$ and $60 \mathrm{~min}$. Figures adapted from ${ }^{5}$.

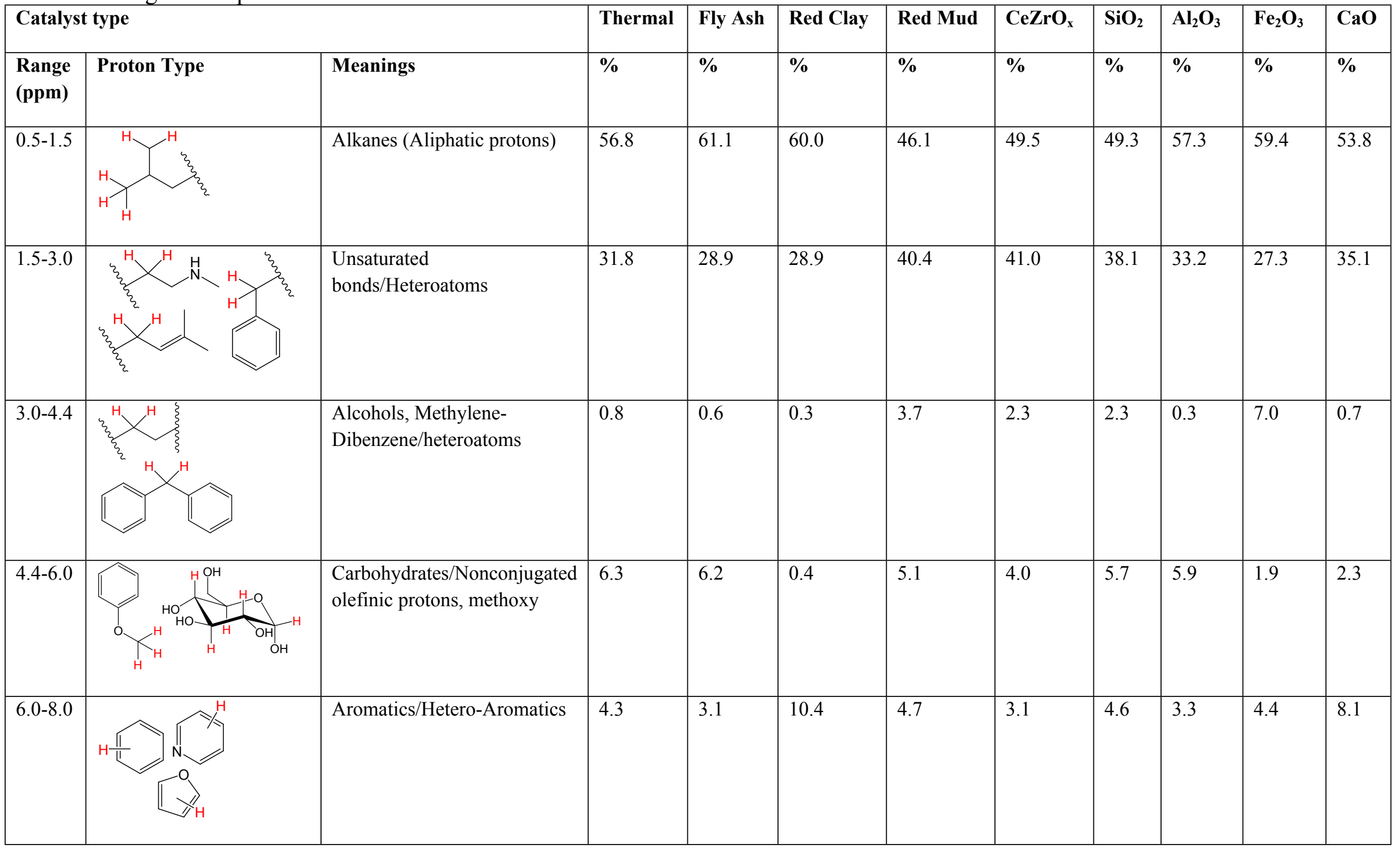


Table S5. Surface area, acidity, and basicity characteristics of oxide catalyst materials.

\begin{tabular}{|c|c|c|c|c|c|c|}
\hline Material & $\begin{array}{c}\mathrm{N}_{2} \text { BET } \\
\text { surface } \\
\text { area } \\
\mathrm{m}^{2} \mathrm{~g}^{-1}\end{array}$ & $\begin{array}{c}\text { acid site } \\
\text { density } \\
\mu_{\mathrm{mol} \mathbf{g}^{-1}}\end{array}$ & $\begin{array}{c}\text { acid site } \\
\text { density } \\
\mu \mathrm{mol} \mathrm{m}^{-2}\end{array}$ & $\begin{array}{c}\text { base site } \\
\text { density } \\
\mu \mathrm{mol} \mathbf{g}^{-1}\end{array}$ & 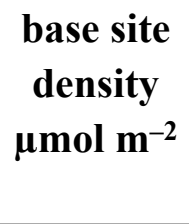 & $\begin{array}{c}\text { ratio of } \\
\text { base- } \\
\text { to-acid } \\
\text { sites }\end{array}$ \\
\hline iron (III) oxide & 5.5 & 0.20 & 0.036 & 3.2 & 0.58 & 16 \\
\hline calcium oxide & 4.0 & 0.59 & 0.15 & 23 & 5.6 & 38 \\
\hline alumina & 180 & 0.57 & 0.003 & 150 & 0.83 & 260 \\
\hline silica & 430 & 1.24 & 0.003 & $<0.002$ & $<0.0001$ & $<0.002$ \\
\hline red mud & 7.0 & 1.23 & 0.18 & 190 & 27 & 160 \\
\hline red clay & 1.8 & 0.09 & 0.050 & 3.8 & 2.118 & 43 \\
\hline fly ash & 2.0 & 0.07 & 0.034 & $<0.001$ & $<0.0002$ & $<0.005$ \\
\hline
\end{tabular}

Table S6. Degassing temperatures of metal components prior to $\mathrm{CO}_{2}$ - and $\mathrm{NH}_{3}-\mathrm{TPD}$ analysis.

\begin{tabular}{lc}
\hline Catalyst & Degassing Temperature $\left({ }^{\circ} \mathbf{C}\right)$ \\
\hline Iron (III) oxide & 450 \\
Silica & 450 \\
Calcium oxide & 800 \\
Alumina & 550 \\
Red clay & 450 \\
Red mud & 300 \\
Fly ash & 550 \\
\hline
\end{tabular}




\section{Section 3 Hydrothermal stability of inexpensive oxides and component oxides}

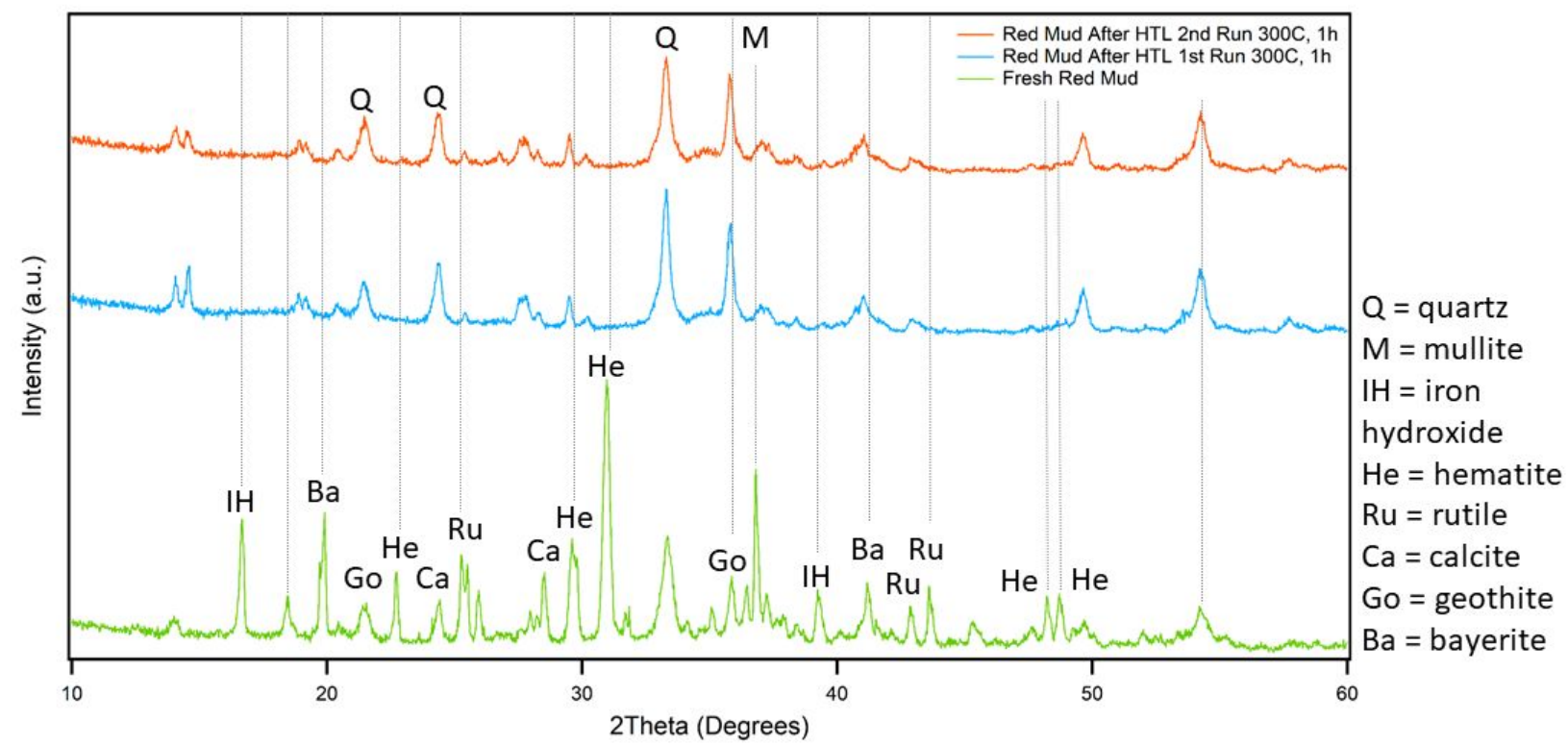

Figure S1. XRD of fresh red mud, compared to after hydrothermal treatment at $300{ }^{\circ} \mathrm{C}$ and 20.68 $\mathrm{MPa}$ for 1 hour.

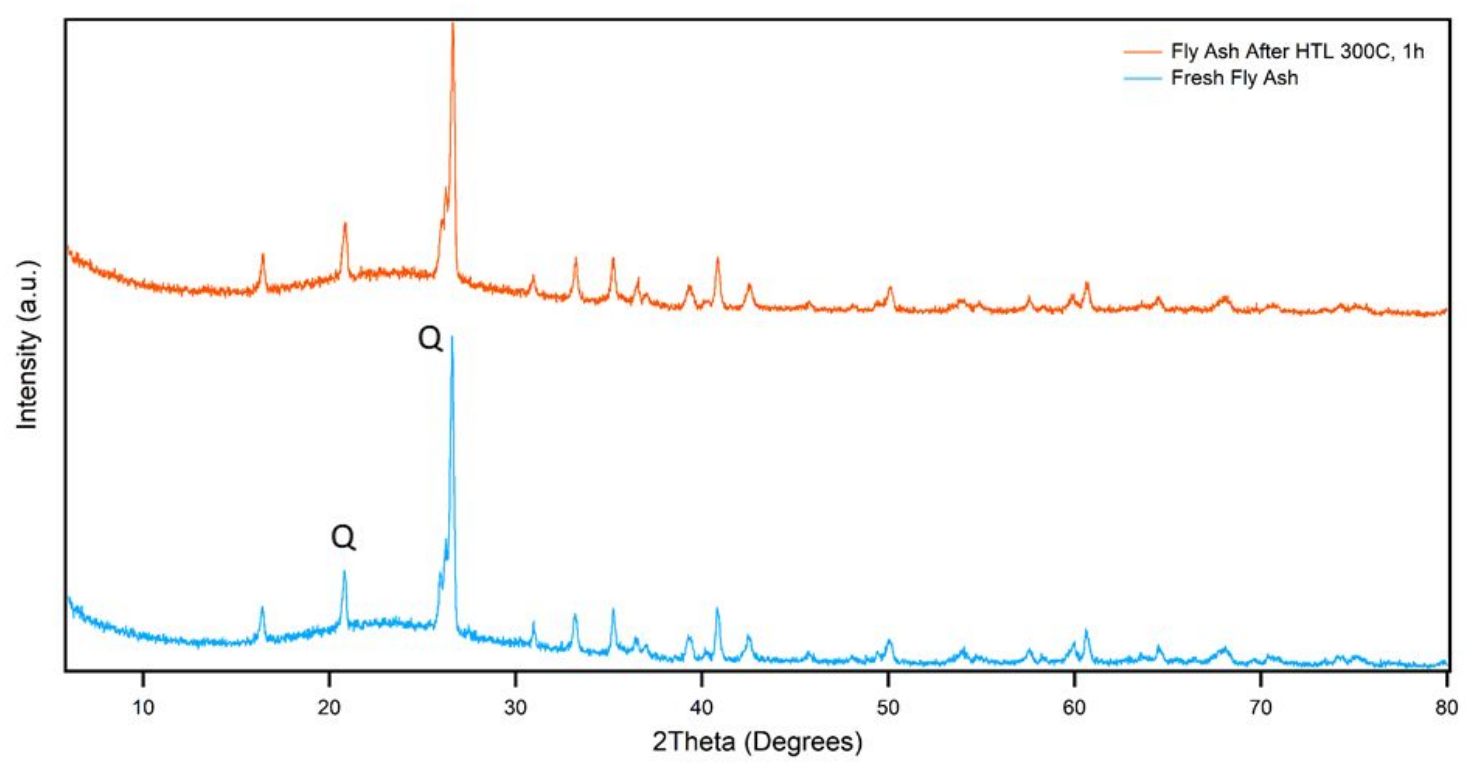

Figure S2. XRD of fly ash, compared to after hydrothermal treatment at $300{ }^{\circ} \mathrm{C}$ and $20.7 \mathrm{MPa}$ for 1 hour. Q: quartz. 


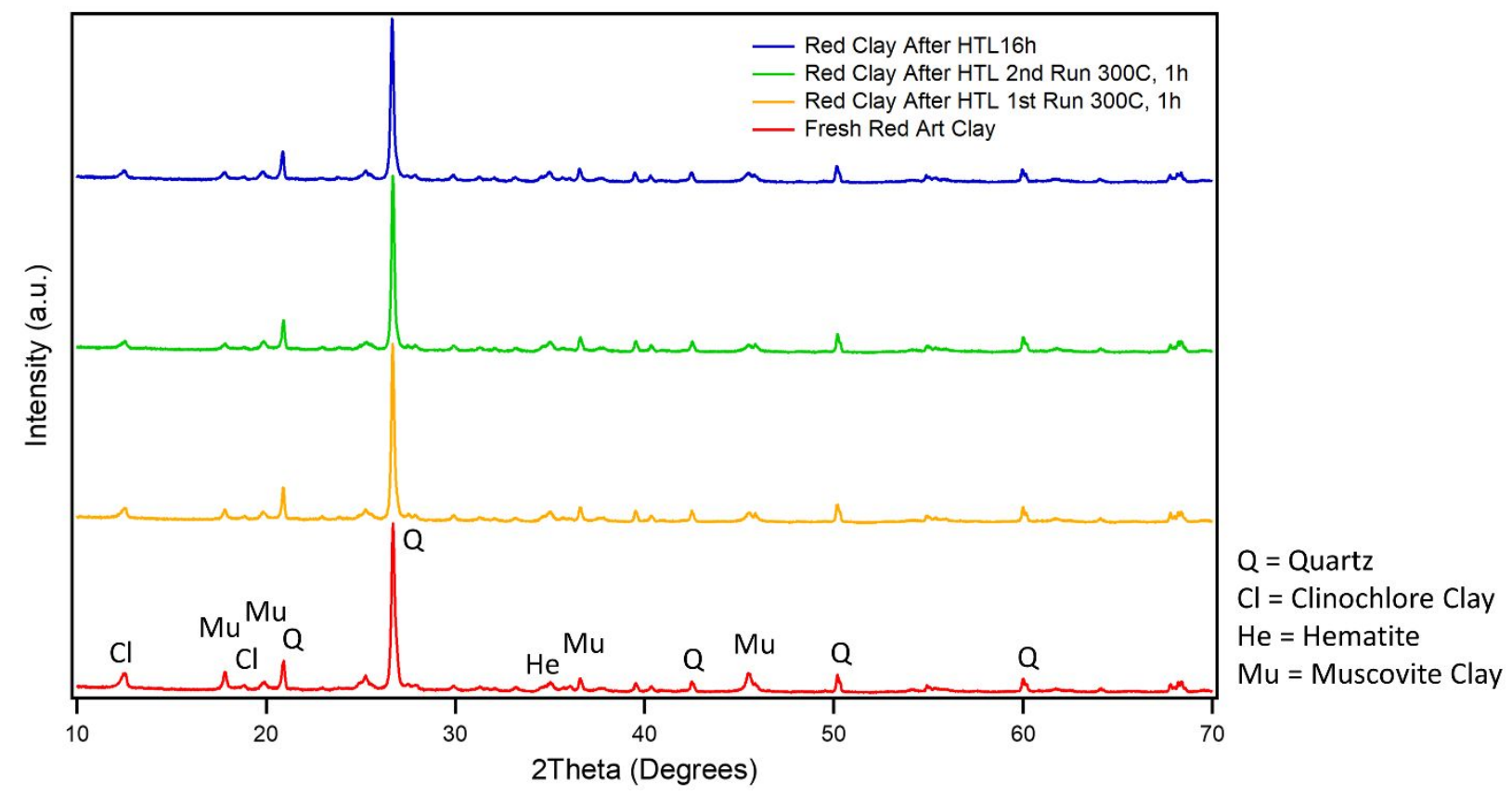

Figure S3. XRD of fresh red clay, compared to after hydrothermal treatment at $300{ }^{\circ} \mathrm{C}$ and 20.7 MPa for 1 and 16 hours. 


\section{Section 4 Characterization of inexpensive oxides, component oxides, and bio- crude oils}

Figures S4-S6 compares representative Raman microscopy spectra obtained from analysis of red clay, fly ash, and red mud with those obtained for the constitutive oxides, $\mathrm{CaO}, \mathrm{Fe}_{2} \mathrm{O}_{3}$, and $\mathrm{SiO}_{2}$ in order to identify the oxide phases presence in the complex waste materials. In contrast with $\mathrm{XRD}$, which is a bulk technique, Raman microspectroscopy provides spatially resolved $(\sim 2 \mu \mathrm{m})$ chemical information to examine the physical heterogeneity of phases present in the mixed metal oxides. Definitive characterization using Raman microspectroscopy is hindered by the complexity of the mixed oxide materials. Instead, spectra of several discrete particles are obtained for each mixed metal oxide to show the heterogeneity of the materials.

Starting with the constitutive oxides, the Raman spectrum of $\mathrm{SiO}_{2}$ consists of weak, broad band at $200-500 \mathrm{~cm}^{-1}$ consistent with amorphous silica. ${ }^{6} \mathrm{Fe}_{2} \mathrm{O}_{3}$ Raman spectrum exhibits bands at 237 , $298,418,502,624$, and $1325 \mathrm{~cm}^{-1}$. These bands are indicative of $\alpha-\mathrm{Fe}_{2} \mathrm{O}_{3}$ hematite phase. ${ }^{7} \mathrm{CaO}$ does now have first order Raman bands and hence we observe no obvious bands. There is only a broad fluorescence exhibited in the spectrum. ${ }^{8}$ The $\mathrm{Al}_{2} \mathrm{O}_{3}$ fluoresced under Raman analysis conditions and useful spectra could not be obtained.

Raman spectra obtained for Red Clay (Figure S4) exhibit bands at 207 and $412 \mathrm{~cm}^{-1}$ indicative of quartz. ${ }^{9}$ The origin of the strong band at $101 \mathrm{~cm}^{-1}$ is unknown. Bands at 209, 345, 412, 540, and $634 \mathrm{~cm}^{-1}$ could indicate clays, such as clinochlore. ${ }^{10}$

Fly ash Raman spectra (Figure S5) exhibit only broad bands at ca. 400 and $700 \mathrm{~cm}^{-1}$, indicating amorphous silicate structure to this material. ${ }^{11}$ Sparse, darkly colored particles in the fly ash samples gave rise to Raman spectra consistent with carbon, as evident from the broad, intense bands at ca, 1345 and $1600 \mathrm{~cm}^{-1} .{ }^{12}$ Fly ash therefore, contains residual carbon particles after the combustion process. XRD patterns show predominately quartz crystalline phase present in the fly ash, with a broad feature centered at $23^{\circ}$, indicating a significant amorphous content (Figure S2). Conversely, Raman indicates that fly ash is composed primarily of amorphous $\mathrm{SiO}_{2}$, with no evidence of quartz bands.

The Raman spectra of red mud are shown in Figure S6, alongside the spectra of the $\mathrm{CaO}, \mathrm{Fe}_{2} \mathrm{O}_{3}$ and $\mathrm{SiO}_{2}$ oxides. The red mud spectra is dominated by bands at 238, 288, 401, 608, 653, and 1314 $\mathrm{cm}^{-1}$ that indicate the $\mathrm{Fe}_{2} \mathrm{O}_{3}$ hematite phase is a significant component in this waste material. A strong band at 401 and weak band at $218 \mathrm{~cm}^{-1}$ indicate the presence of quartz. ${ }^{9}$ The band at 143 $\mathrm{cm}^{-1}$ is assigned to anatase titanium dioxide. ${ }^{13}$ The sharp band in one red mud spectrum at 1073 $\mathrm{cm}^{-1}$ is likely calcite observed at $1085 \mathrm{~cm}^{-1} .{ }^{14}$ The weak band at $1057 \mathrm{~cm}^{-1}$ for red mud has been previously assigned to cancrinite and/or gibbsite. ${ }^{15}$ Previously, Palmer and Frost characterized red mud using Raman spectroscopy. ${ }^{15}$ The minerals of hematite, cancrinite, whewellite, gibbsite, boehmite, calcite, anatase, and quartz were identified. We observe similar Raman spectra for red mud to Palmer and Frost, ${ }^{15}$ which is also consistent with XRD results. 


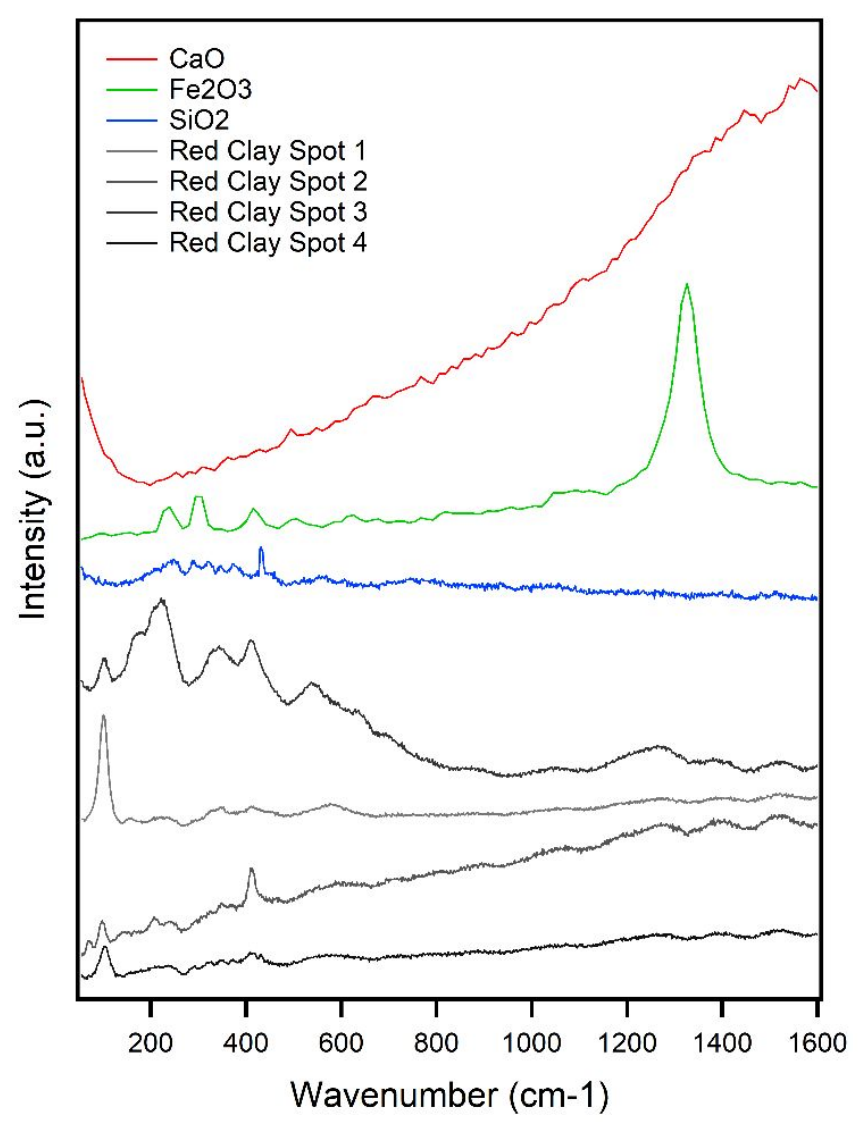

Figure S4. Experimental Raman spectra of red clay samples with different spots and other single metal oxides. 


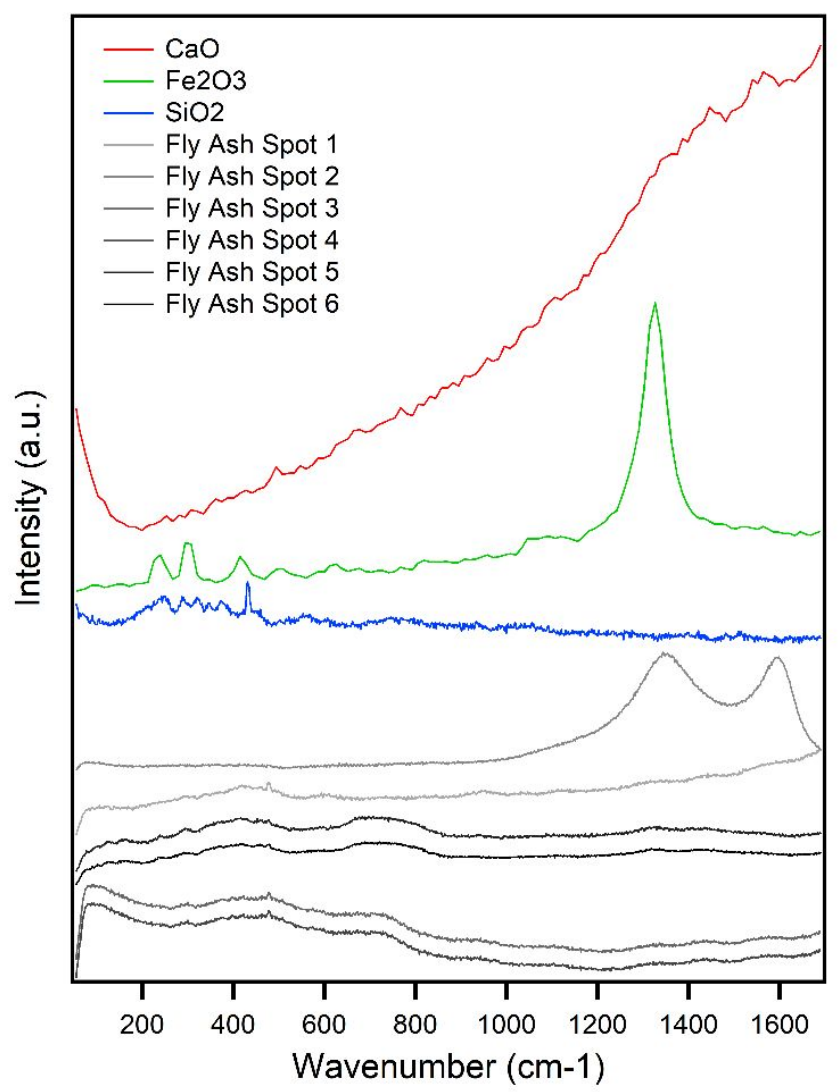

Figure S5. Experimental Raman spectra of fly ash samples with different spots and other single metal oxides. 


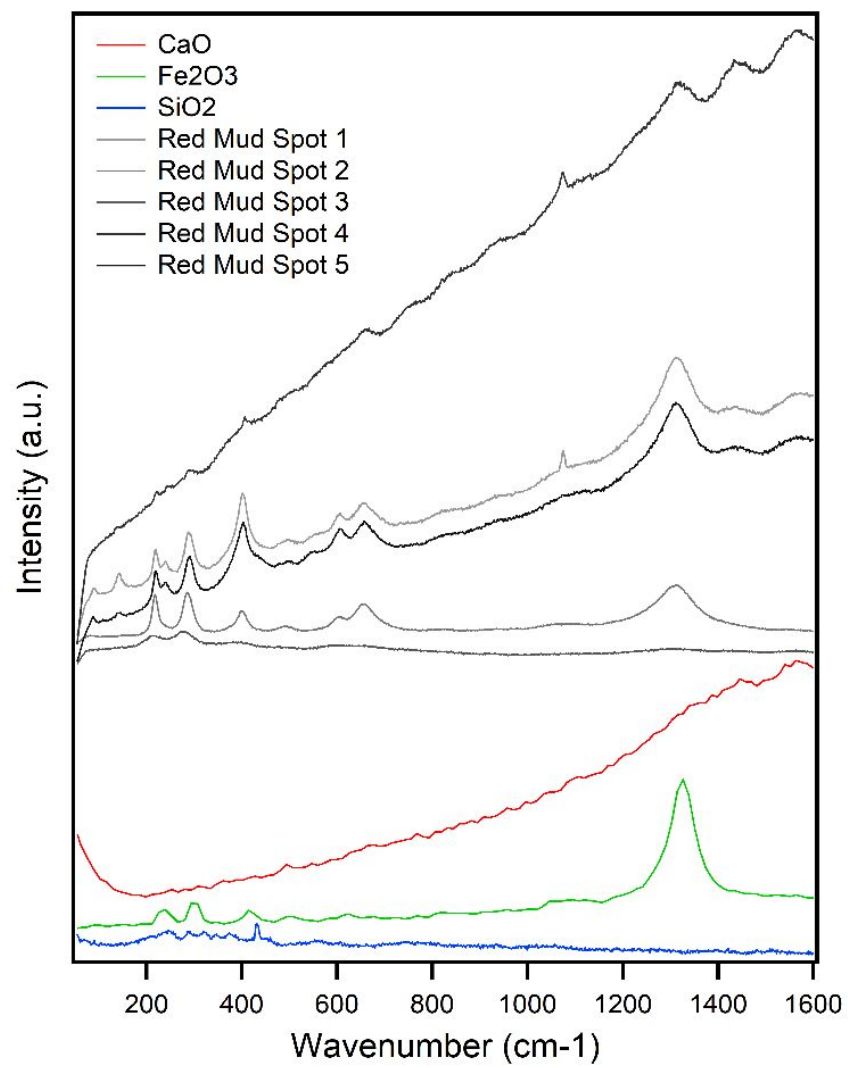

Figure S6. Experimental Raman spectra of red mud samples with different spots and other single metal oxides. 


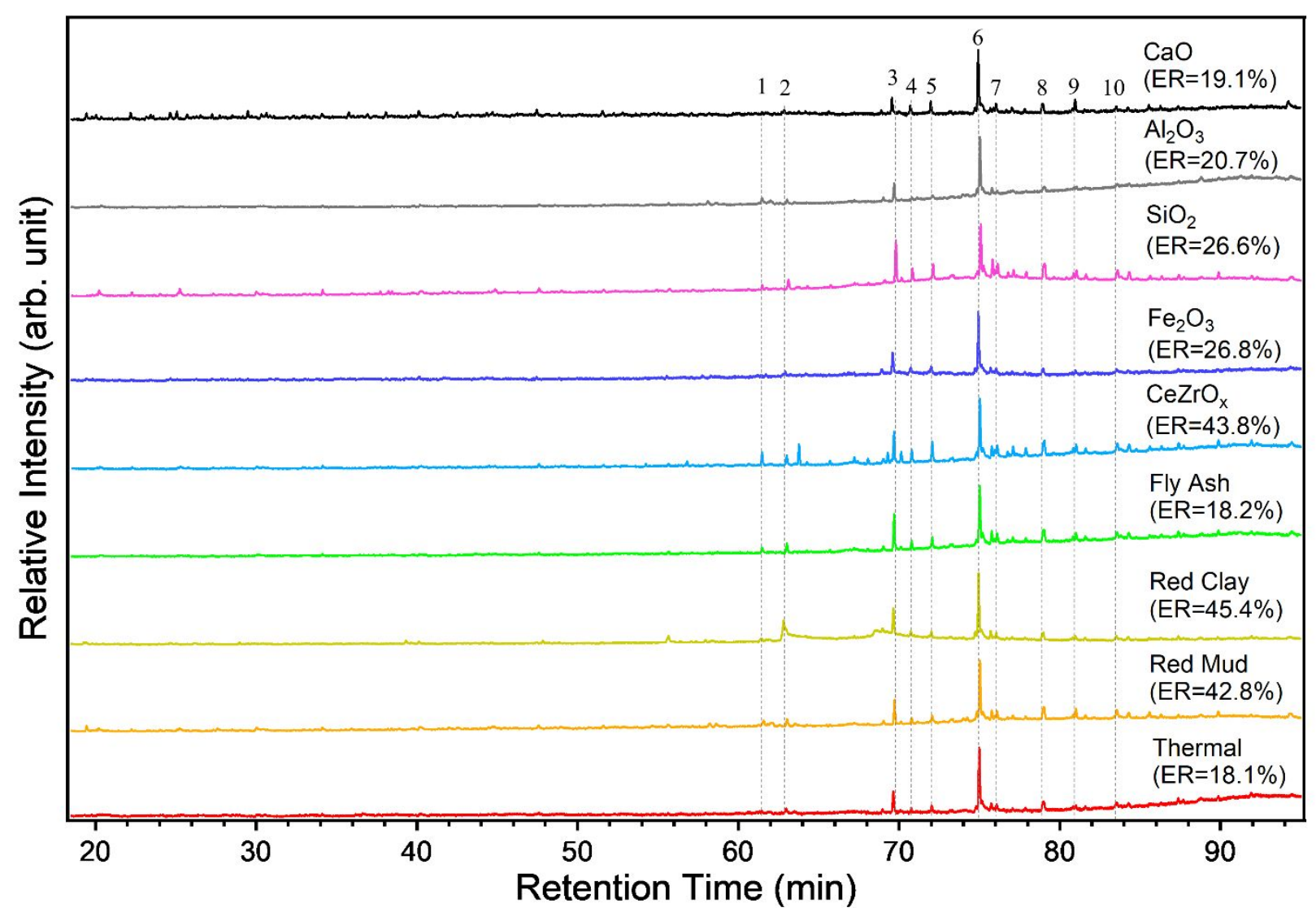

Figure S7. GC-MS chromatogram of the bio-crude oils produced using different catalysts. ER: Energy Recovery. (1) 61.5 min Hexadecanoic acid, methyl ester; (2) 63.0 min Tetradecanamide; (3) $69.6 \mathrm{~min}$ Octadecanamide; (4) $70.8 \mathrm{~min}$ N-Methyldodecanamide; (5) $72.1 \mathrm{~min} \mathrm{~N}, \mathrm{~N}-$ Dimethyldodecanamide; (6) 75.0 min 9-Octadecenamide, (Z)-; (7) 76.1 min Octadecanamide, Nbutyl-; (8) 79.0 min Hexanoic acid, morpholide; (9) 81.0 min Pyrrolidine, 1-(6-methyl-1oxooctadecyl)-; (10) 83.6 min Oleic diethanolamide. 


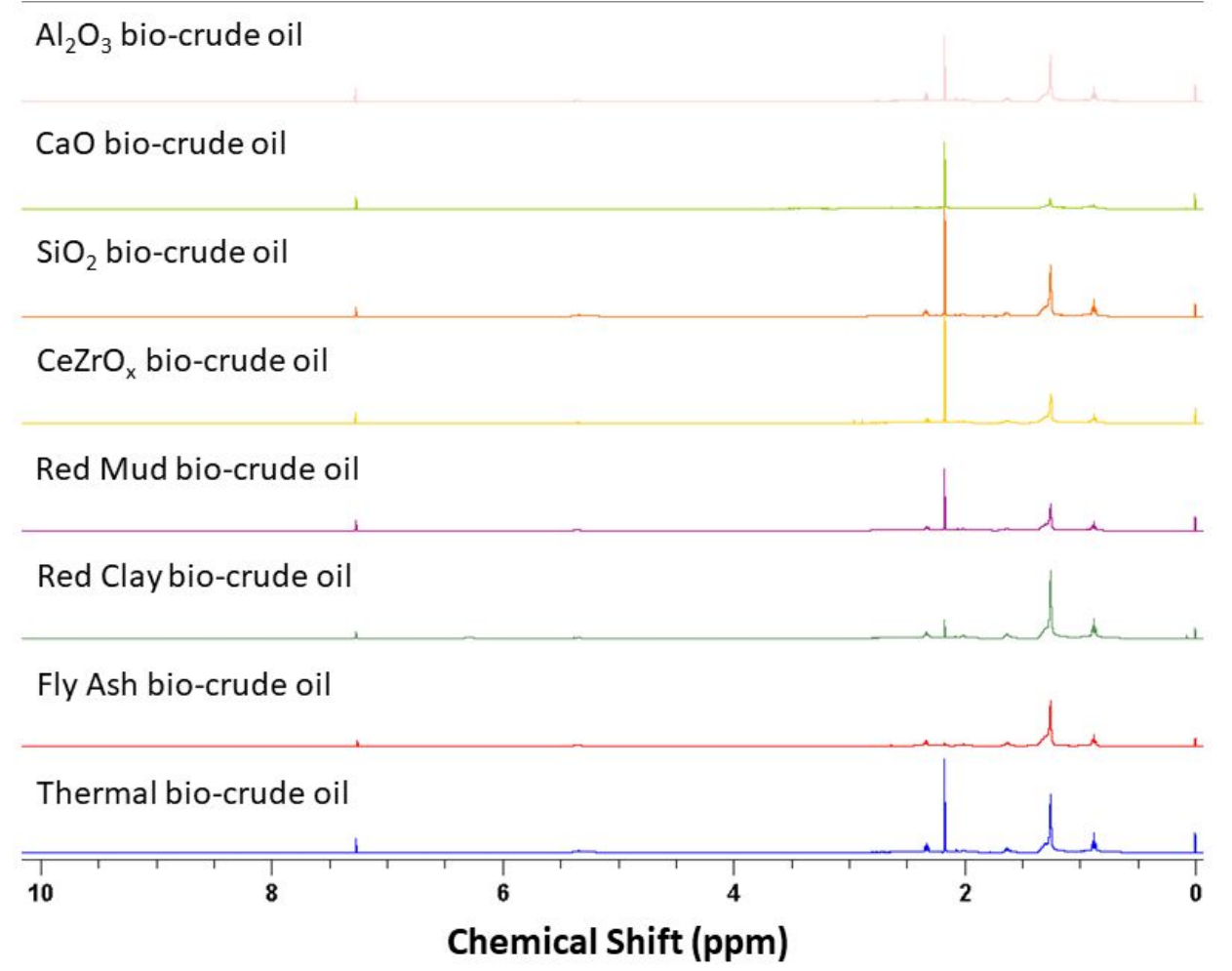

Figure S8. ${ }^{1} \mathrm{H}$ NMR spectra of bio-crude oils obtained from HTL and CHTL of 15 wt.\% food waste using different catalysts under $300{ }^{\circ} \mathrm{C}$ and $60 \mathrm{~min} . \mathrm{Fe}_{2} \mathrm{O}_{3}$ data was unavailable due to the limited amount of oil sample. 


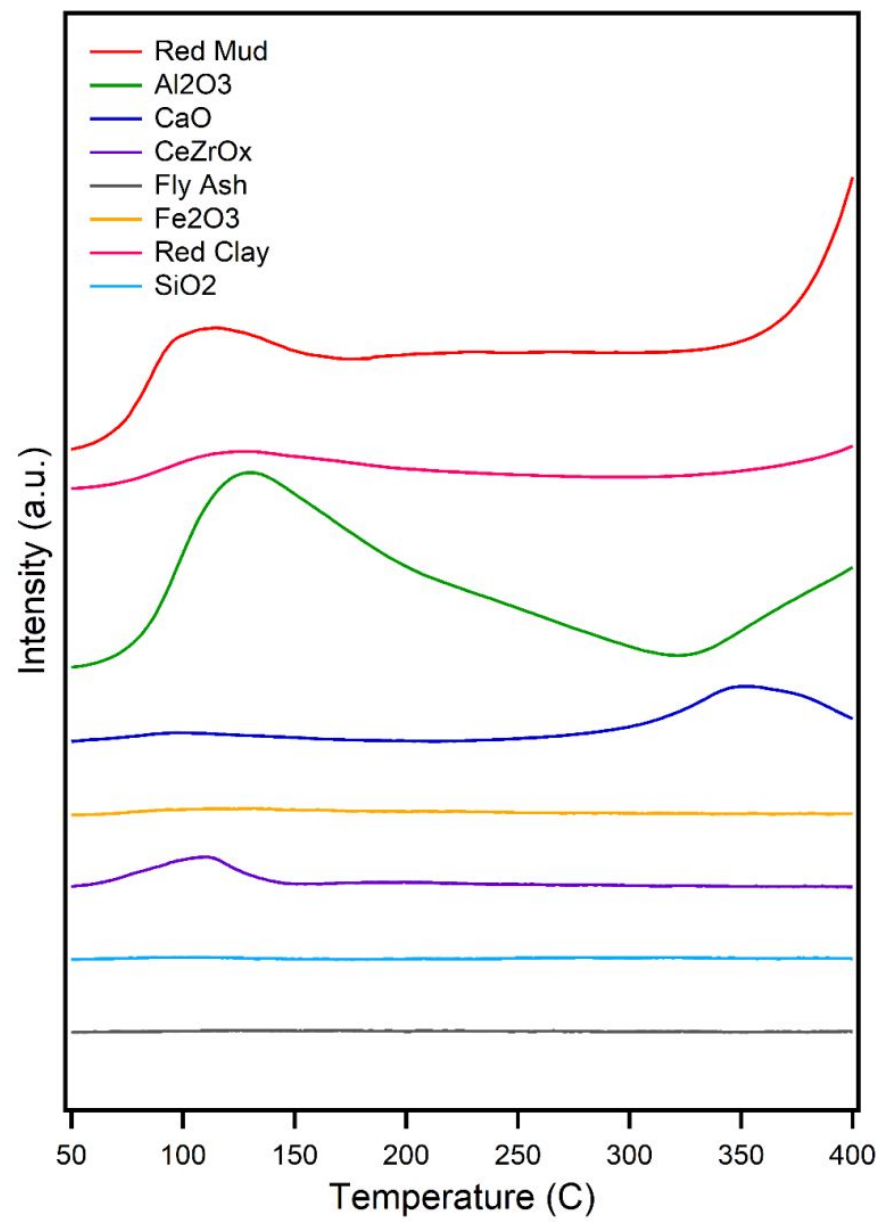

Figure S9. $\mathrm{CO}_{2}$-TPD base and acid site characterization of oxide catalysts. 


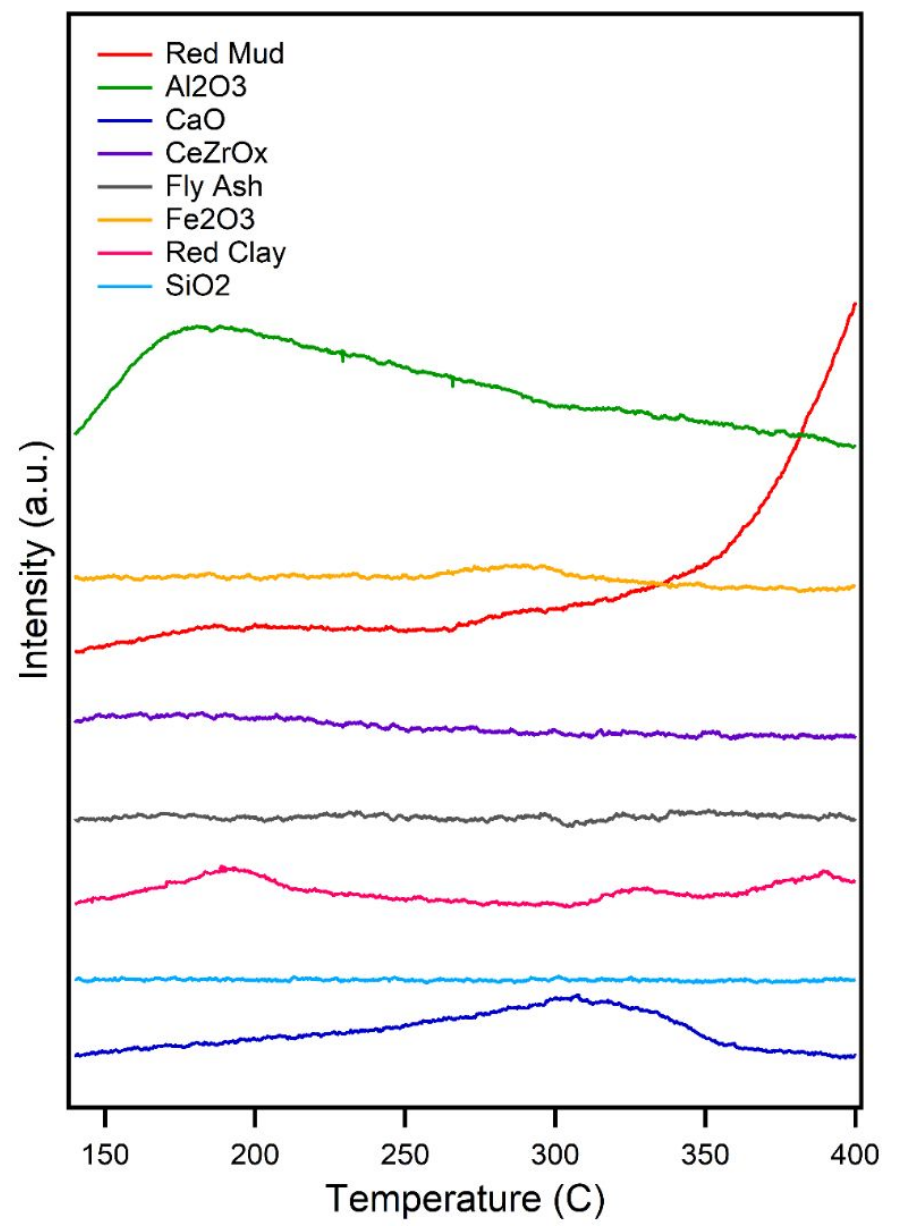

Figure S10. $\mathrm{NH}_{3}-\mathrm{TPD}$ base and acid site characterization of oxide catalysts. 

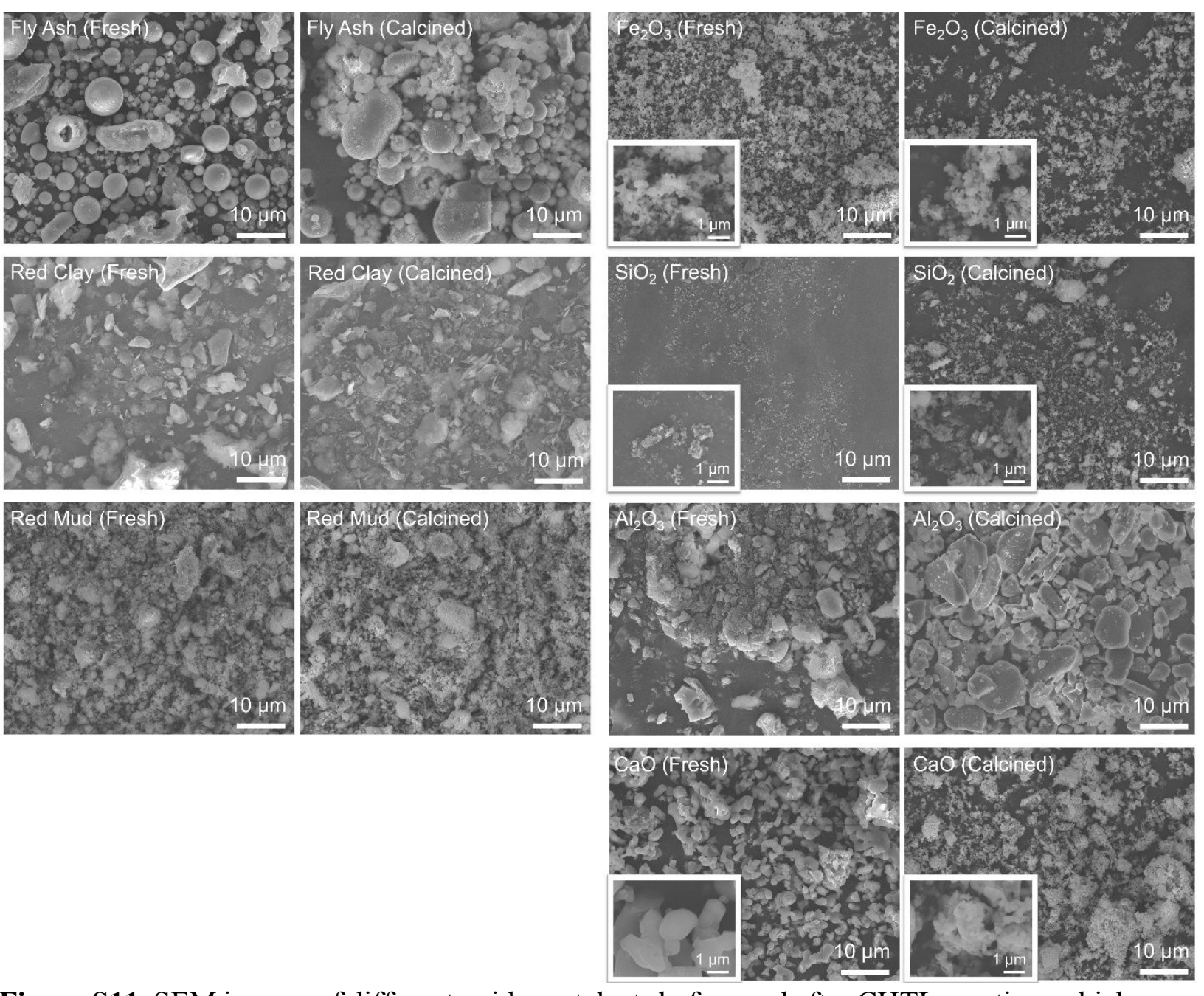

Figure S11. SEM images of different oxides catalysts before and after CHTL reaction, which were represented by "Fresh" and "Calcined", respectively. Internal boxes show zoomed image. 


\section{Reference}

1. Rodrigues, E.; Keller, T.; Mitchell, S.; Pérez-Ramírez, J., Hydroxyapatite, an exceptional catalyst for the gas-phase deoxygenation of bio-oil by aldol condensation. Green Chem. 2014, 16 (12), 4870-4874, 10.1039/C4GC01432D.

2. Käßner, P.; Baerns, M., Comparative characterization of basicity and acidity of metal oxide catalysts for the oxidative coupling of methane by different methods. Appl. Catal., A 1996, 139 (1-2), 107-129, 10.1016/0926-860X(95)00335-5.

3. Trombetta, M.; Busca, G.; Lenarda, M.; Storaro, L.; Ganzerla, R.; Piovesan, L.; Lopez, A. J.; Alcantara-Rodriguez, M.; Rodríguez-Castellón, E., Solid acid catalysts from clays: Evaluation of surface acidity of mono-and bi-pillared smectites by FT-IR spectroscopy measurements, $\mathrm{NH}_{3}$-TPD and catalytic tests. Appl. Catal., A 2000, 193 (1-2), 55-69, 10.1016/S0926-860X(99)00413-5.

4. Zhang, M.; Guo, H.; El-Korchi, T.; Zhang, G.; Tao, M., Experimental feasibility study of geopolymer as the next-generation soil stabilizer. Constr Build Mater. 2013, 47, 1468-1478, 10.1016/j.conbuildmat.2013.06.017.

5. Mullen, C. A.; Strahan, G. D.; Boateng, A. A., Characterization of various fast-pyrolysis bio-oils by NMR spectroscopy. Energy Fuels 2009, 23 (5), 2707-2718, 10.1021/ef801048b.

6. Alessi, A.; Agnello, S.; Buscarino, G.; Gelardi, F., Raman and IR investigation of silica nanoparticles structure. J Non-Cryst. Solids 2013, 362, 20-24, 10.1016/j.jnoncrysol.2012.11.006.

7. De Faria, D.; Venâncio Silva, S.; De Oliveira, M., Raman microspectroscopy of some iron oxides and oxyhydroxides. J Raman Spectrosc. 1997, 28 (11), 873-878, 10.1002/(SICI)1097-4555(199711)28:11<873::AID-JRS177>3.0.CO;2-B.

8. Schmid, T.; Dariz, P., Shedding light onto the spectra of lime: Raman and luminescence bands of $\mathrm{CaO}, \mathrm{Ca}(\mathrm{OH})_{2}$ and $\mathrm{CaCO}_{3}$. J Raman Spectrosc. 2015, 46 (1), 141-146, $10.1002 / j \mathrm{js} .4622$.

9. $\quad$ Biswas, R. K.; Khan, P.; Mukherjee, S.; Mukhopadhyay, A. K.; Ghosh, J.; Muraleedharan, K., Study of short range structure of amorphous Silica from PDF using Ag radiation in laboratory XRD system, RAMAN and NEXAFS. J Non-Cryst Solids 2018, 488, 1-9, 10.1016/j.jnoncrysol.2018.02.037.

10. Jovanovski, G.; Makreski, P., Minerals from Macedonia. XXX. Complementary use of vibrational spectroscopy and X-ray powder diffraction for spectra-structural study of some cyclo-, phyllo-and tectosilicate minerals. A review. Maced J Chem Chem En 2016, 35 (2), 125 $155,10.20450 /$ mjcce.2016.1047.

11. Tosheva, L.; Brockbank, A.; Mihailova, B.; Sutula, J.; Ludwig, J.; Potgieter, H.; Verran, J., Micron-and nanosized FAU-type zeolites from fly ash for antibacterial applications. J. Mater. Chem. 2012, 22 (33), 16897-16905, 10.1039/C2JM33180B. 
12. Wang, Y.; Alsmeyer, D. C.; McCreery, R. L., Raman spectroscopy of carbon materials: structural basis of observed spectra. Chem. Mater. 1990, 2 (5), 557-563, 10.1021/cm00011a018.

13. Tuschel, D., Molecular Spectroscopy Workbench Raman Spectroscopy and Polymorphism. Spectroscopy 2019, 34 (3), 10-21.

14. De La Pierre, M.; Carteret, C.; Maschio, L.; André, E.; Orlando, R.; Dovesi, R., The Raman spectrum of $\mathrm{CaCO}_{3}$ polymorphs calcite and aragonite: a combined experimental and computational study. J. Chem. Phys. 2014, 140 (16), 164509, 10.1063/1.4871900.

15. Palmer, S. J.; Frost, R. L., Characterisation of bauxite and seawater neutralised bauxite residue using XRD and vibrational spectroscopic techniques. J. Mater. Sci. 2009, 44 (1), 55-63, 10.1007/s10853-008-3123-y. 